\title{
Three perspectives on the role of teacher beliefs in the language classroom
}

\author{
Line Krogager Andersen, University of Southern Denmark
}

\begin{abstract}
This study explores the role of teacher beliefs in two teachers' implementation of a collaboratively planned teaching activity into classroom practice. It is a retrospective case study aiming to explain how the difference between two teachers' realisations of a specific bilingual teaching activity may be seen as related to their beliefs about language learning and teaching. The role of teacher beliefs for language teaching practice has been the subject of much research, although the nature of the relationship remains contested. This study explores a new approach to the puzzle by combining new and existing perspectives on teacher beliefs in the form of enacted, professed and implicit beliefs. The study re-examines data from a larger action research study through 4 cycles of analysis and interpretation, moving from observed teaching practices to the three perspectives on teacher beliefs to provide a description of the complex interplay between beliefs and practice. The analysis shows that the combination of the different perspectives on teacher beliefs allows for a meaningful interpretation of the relationship between teacher beliefs and teaching practice, that the two teachers' beliefs about language learning and teaching play an important role in their transformation of teaching plans to teaching practice and that their different practices lead to different language learning affordances in the two classrooms. The article concludes by suggesting that the interplay between teaching activities, students' engagement and teacher beliefs may be a fruitful place of inquiry for future research.
\end{abstract}

Keywords: teacher beliefs, enacted beliefs, language awareness, plurilingual teaching, affordances for language awareness, classroom research, action research

\section{Introduction}

This comparative case study is based on an empirical rich point (a surprising observation made in ethnographic field work, cf. Agar, 2000, p. 94; Hornberger, 2013, p. 101) observed in the context of a larger action research study (Krogager Andersen, 2020) aimed at promoting affordances for language awareness through a plurilingual approach applied in the teaching of 5th grade Danish L1, English L2 and German L3 in a Danish municipal school. Throughout the year-long action research study, the participating teachers collaborated with each other and with me in the role of the action researcher (Bradbury-Huang, 2010; Burns \& Worsley, 2015; Hersted, Ness, \& Frimann, 2020) to find ways of applying the plurilingual approach in their own teaching.

Corresponding author's email: lika@sdu.dk

eISSN: 1457-9863

Publisher: University of Jyväskylä, Language Campus

(C) 2021: The authors

https://apples.journal.fi

https://doi.org/10.47862/apples.103078 
The incident which caught my interest (the rich point) occurred in the context of an L1-L2 bilingual teaching activity, which was planned collaboratively to be carried out by two of the teachers in parallel sessions. There was a striking difference between the teaching observed in the two classrooms which led me to wonder how a parallel teaching activity which was planned collaboratively could play out so differently at the hands of the two teachers, and whether theories of teacher beliefs (Borg, 2003,2006, 2018; Kubanyiova \& Feryok, 2015; Kalaja et al., 2015) might help explain this difference.

Inspired by Alvesson \& Sköldberg's Reflexive Methodology (2009), I decided to pool and analyse all my previously collected ethnographic data to search for a meaningful interpretation of this difference in practice. Thus, the design of the study is a retrospective case study combining pre-existing data in new ways to compare the way in which the two teachers taught these lessons, and consider the role of teacher's beliefs for the ways in which the common plans were transformed into practice.

\section{Theoretical points of departure}

\subsection{Teachers' beliefs about language learning}

The term teacher beliefs is related to the study of teacher cognition, defined by Borg (2006, p. 272) as "an inclusive term referring to the complex, practically-oriented, personalized, and context-sensitive networks of knowledge, thoughts and beliefs that language teachers draw on in their work." In spite of this stated inclusiveness of the term, a proliferation of concepts and definitions has emerged over time. As pointed out by Kubanyiova \& Feryok (2015), many of these are based on a cognitivist understanding of cognition and have been preoccupied with the uncovering of teachers' mental constructs.

Others, founded in the social turn, have focused on "situated, dynamic and embodied knowing in action" (Kubanyiova \& Feryok, 2015, p. 438). This study is based on a socio-cognitive understanding of teaching and learning (LarsenFreeman \& Cameron, 2008), closely related to the ecological approach proposed by Kubanyiova and Feryok (2015, p. 436) "to embrace the complexity of teachers' inner lives in the context of their activity."

The socio-cognitive stance attempts to integrate the highly situated social perspective on teacher beliefs with the somewhat more distanced cognitivist perspective by combining three different perspectives on beliefs which may be seen respectively as more socially and more cognitively founded (enacted, professed and implicit beliefs, see below).

The relationship between teaching practice and teacher beliefs is central to research within teacher beliefs (Borg, 2018). Empirical studies have found this relationship to be a close, but complex one (Kubanyiova, 2016; Li, 2013; Meier, 2016; Ruohotie-Lyhty, 2015; Sakui \& Gaies, 2003; Woods, 2003).

The complexity of this relationship is illustrated by Borg (2018), who notes that teachers hold a multitude of beliefs which are "organized into networks or belief systems." He argues that simplistic conceptualizations and research designs tend to dismiss this complexity. To avoid this, one may consider beliefs to be dynamic constructs organised into networks and temporally and socially situated (Andrews \& Yin, 2018; Borg, 2018; Centeno \& Ponce, 2019; Li, 2013) and recognise that the 
description of such dynamic and situated constructs cannot rest solely on the prevalent method of eliciting beliefs in settings removed from the classroom.

In fact, teaching practice and the beliefs expressed explicitly in interview situations may be expected to differ - as Haukås (2016, p. 14) points out, "it is naïve to believe that a teacher's reported beliefs accurately reflect what occurs in the classroom." This paradoxical nature of the relationship between reported beliefs and observed practice necessitates the distinction between professed beliefs (the beliefs that teachers report explicitly) and enacted beliefs (the beliefs that can be inferred from the teaching practice as observed), as pointed out by Borg (2018).

Focussing on enacted beliefs means viewing teachers' dynamic choices in the classroom as a source of insight into the way teachers "see and make sense of their teaching worlds" (Kubanyiova, 2020, p. 54) and has been shown to yield valuable results. If one assumes that a teacher's practice is always meaningful in relation to his or her belief system, what remains to consider in each instance is what belief would make a certain classroom choice meaningful. Such a mode of analysis does not presume that all that teachers ever do is based on their innermost beliefs, but rather that it is never random. Kubanyiova (2015) illustrates how this can be done through a skilful combination of ethnographic data sets from the same teacher. In this study, I attempt to interpret salient characteristics of teachers' classroom practice as enactments of certain beliefs.

To gain a fuller perspective on a teacher's belief system, I combine this focus with a perspective on the same teacher's professed beliefs. Professed beliefs are expressed through teachers' explicit statements about the topic in question, and the type of belief most frequently investigated in beliefs research (cf. Borg, 2003, 2006,2018 ). They provide an important perspective on the teacher's ideas on an abstract level, although they have been found often not to match what the same teachers do in the classroom (Borg, 2018; Centeno \& Ponce, 2019; Skott, 2015), suggesting that this perspective cannot stand alone $(\mathrm{Li}, 2013)$.

A third perspective on beliefs is that they may surface indirectly in discourse through metaphors, presuppositions and entailments (Kramsch, 2003; Lakoff \& Johnson, 2003). As metaphor theory and discourse analysis have shown us (Fairclough, 1992; Lakoff \& Johnson, 2003; Underhill, 2011) the way we talk about things both reflects certain worldviews and contributes to their construction, which is why I have found the teachers' discourse on language and language learning and teaching to be an instructive perspective on their beliefs. Beliefs identified through this discourse analytical approach cannot correctly be termed professed beliefs, since they are expressed indirectly in discourse, but their identification may in my opinion very well contribute to our understanding of a teacher's belief system. I have chosen to include them in this study under the term implicit beliefs.

\subsection{Plurilingual affordances for language awareness}

The teaching activity at the centre of this study was part of a teacher-researcher collaborative effort to establish plurilingual affordances for language awareness. Language awareness is the focal point of a transdisciplinary field of research established on the basis of seminal work by Hawkins (1999), Fairclough (1992) and James \& Garrett (1992), and has been studied in a wide variety of linguistic contexts, ranging from L1 teaching (e.g. Caceres-Lorenzo, 2014; Dufva \& Alanen, 2005) via L2/L3 teaching (e.g. Ammar et al., 2010; Angelovska, 2018; Simard \& 
Gutiérrez, 2018) to a plethora of different multilingual contexts (e.g. Jessner, 1999; Palfreyman \& Al-Bataineh, 2018; Radinger, 2018).

This study connects to the pedagogical strand of language awareness research, focusing on language awareness as enacted in the classroom (Dufva \& Alanen, 2005; Laursen, 2019; Moore, 2014) and on the development of teaching for language awareness (Daryai-Hansen et al., 2015; Gunning et al., 2016). It builds on the concept of affordances for language awareness which implies a dialogical perspective on teaching and learning and invites us to consider language awareness as a both cognitive and social phenomenon (Dufva \& Alanen, 2005; Lier, 2004), that is, as something which refers both to a state of mind and an array of practices, in this case specifically noticing (Schmidt, 1995), cross-linguistic comparison and metalinguistic reflection (Krogager Andersen, 2020; Simard \& Gutiérrez, 2018).

For the purposes of this study, I define affordances for language awareness as linguistic and metalinguistic resources in the classroom whose presence invites these practices on the part of the students. Such affordances may be new vocabulary or syntax presented by the teacher, a song sung by a fellow student, or any other resource which prompts this type of student engagement with language. Following the socio-cognitive perspective on teaching, affordances for language awareness are seen to emerge out of the intersubjective interplay between students, teacher and content matter; i.e. there is no simple relationship between the teaching materials used by the teacher and the language aware practices that the students engage in.

The idea of establishing plurilingual affordances for language awareness draws on previous research into the role of plurilingual resources in the development of language awareness (Bialystok, 2011; Daugaard, 2015; Jessner, 2016; Krogager Andersen, 2020; Laursen, 2019; Oliveira \& Ancâ, 2018).

\section{Design and methodology}

\subsection{Research question}

The research question of the present study is:

How may the difference between two teachers' realisations of a specific bilingual teaching activity be seen as related to their beliefs about language learning and teaching?

\subsection{Research setting and participants}

This study was conducted in two $5^{\text {th }}$ grade classrooms in a suburban Danish primary school (age 11-12). Danish K-12 is a unitary system characterised by a strong focus on the inclusion of special needs students in the mainstream classroom and a relatively high degree of digitization in the form of students and teachers working on computers, tablets and digital learning platforms, and using the classroom smart board. The specific classes concerned were standard sized (25-28 students), with only one to two bilingual students per class.

Two teachers participated in this study. Teacher A is a teacher of Danish (L1), Cooking and Religion; Teacher B is a teacher of Danish, English (L2) and History. They are of a similar age (both close to 30 years old); each has a few years of 
teaching experience and has been at the school in question for over two years. They both have BA's in teaching with special focus on the subjects they teach.

The bilingual activity took place in L1 Danish and L2 English class. The students in this particular year have had English L2 teaching since their $3^{\text {rd }}$ year. The L1 and L2 subjects are not traditionally considered related subjects in the Danish school system and research has shown the teaching traditions within the two subjects to be very different. L1 teaching materials tend to focus on literature and literacy, metalinguistic content being presented within a prescriptive and structuralist framework (Bremholm et al., 2017), whereas reports on foreign language teaching in Denmark show that L2 teachers favour a communicative approach (Andersen \& Blach, 2010; EVA, 2003).

The teaching activity and data collection that form the basis of this article were conducted as part of an action research project (Amrani et al., 2019; Krogager Andersen, 2020) in which three teachers and the researcher collaborated to establish plurilingual affordances for language awareness (cf. section 2.2) involving plurilingual teaching activities and working across subject boundaries. Throughout the project, five to ten classes weekly were observed, and the teacherresearcher group met at fortnightly reflection meetings to discuss and reflect on the challenges and potentials related to the plurilingual teaching carried out in the classrooms, and to plan new activities. This study zooms in on one such activity.

\subsection{Teaching activity}

The teaching activity was an awareness-raising activity on machine translation, developed collaboratively by the teachers and the researcher within the action research framework (Hersted et al., 2020; McNamee, 2020) and chosen on the basis of teachers' experiences with students' use of machine translation. The activity was intended for parallel implementation in a double period in each classroom irrespective of subject boundaries.

The activity was based on a Danish machine translation of an English text on cheerleaders that two students had come across when doing a project on dangerous sports. The plan proposed by the researcher was to let students explore the Danish version of the text first, with a view to noticing the parts that were difficult to understand or in other ways unusual, to promote attention to linguistic form and meaning. After this initial exploration, students were to be given the Englishlanguage original to compare it with the translation and look for correspondences which might explain the strangeness of the Danish text. This comparative element was included to enhance affordances for metalinguistic reflection.

\subsection{Data}

Three sets of data are used in this study, all selected retrospectively from the dataset of the main study (Krogager Andersen, 2020) on the basis of their relevance to the research question of this substudy. These consist of ethnographic observational classroom data, interview data and data from reflection meetings. The observational data are in the form of field notes and video, the interview and reflection meeting data are both in the form of audio files. Central excerpts of the audio data were transcribed using a broad, interaction-focused transcription style (Kvale \& Brinkmann, 2009). 
An overview of the data is given in table 1 below. The parentheses indicate the code which will be used to refer to each dataset in the subsequent analyses.

Table 1. Data overview.

\begin{tabular}{lll}
\hline \multicolumn{1}{c}{ Data/Teacher } & \multicolumn{1}{c}{ Teacher A } & \multicolumn{1}{c}{ Teacher B } \\
\hline Interview (prior) & $\begin{array}{l}45 \text { min. audio, excerpts } \\
\text { transcribed (IA) }\end{array}$ & $\begin{array}{l}53 \text { min. audio, excerpts } \\
\text { transcribed (IB) }\end{array}$ \\
\hline $\begin{array}{l}\text { Pre-activity reflection } \\
\text { meeting }\end{array}$ & 90 min. audio, excerpts transcribed (RM) \\
\hline Classroom observation & $\begin{array}{ll}\text { Ethnographic field notes \& 45 } \\
\text { min. video }\end{array}$ & $\begin{array}{l}\text { Ethnographic field notes \& 90 } \\
\text { min. video }\end{array}$ \\
& Danish Class, Class A (OA) & English Class, Class B (OB) \\
\hline
\end{tabular}

The different datasets contribute as follows: the classroom observations form the basis of the research question, since the difference between the two teachers' realizations of the common teaching activity is observed here. The reflection meeting data serve to show the teachers' explicit reflections regarding the teaching activity. These data stem from teachers' discussions of teaching and reflection on the goals and potentials of the planned teaching activity at a meeting prior to the teaching activity itself.

The interview data collected 6 months prior allow for a consideration of the relationship between the teachers' actions and reflections in relation to the planning and implementation of this specific teaching activity, and their earlier, more general reflections on language and language learning expressed in the interviews.

The combination of these sets of data allows for a comprehensive view of the teachers' beliefs by combining data on professed beliefs, beliefs implicit in discourse and beliefs enacted in teaching practice. In this way, I hope to cast a light on some of the complexities in the interactive relationship between teacher beliefs and teaching practice.

\subsection{Analysis}

The analysis is structured in four different sections. The first section describes the classroom practices observed in the form of an analysis of lesson structure (inspired by Larsen-Freeman, 2000), comparing the lessons of the two teachers in terms of structure, timing, framing of the task, teacher roles and student engagement. This section describes the striking difference between the two teachers' realisations of the activity which initially triggered this study.

The next section interprets the practice observed as enactments of teacher beliefs (Borg, 2018; Centeno \& Ponce, 2019; Woods, 2003). In this section, I draw out the most salient characteristics of each teacher's implementation of the teaching activity and interpret these reflexively (Alvesson \& Sköldberg, 2009) by considering which beliefs could meaningfully be attributed to the teachers in light of this practice. This reflexive interpretation of teacher practice serves as a second cycle of analysis, moving from a descriptive to an interpretive level, and thus providing the grounds for a comprehensive perspective on the teacher's beliefs.

In the third section, a more frequently used perspective (cf. Haukås, 2016) on teacher beliefs is employed, focusing explicitly on the teacher's professed beliefs about language learning and teaching, and considering their relevance for the 
practice observed. These professed beliefs are drawn from the teachers' discourse at the reflection meeting and the prior interview.

The fourth perspective adds a final dimension to the analysis of the teachers' beliefs, employing metaphor theory (Kramsch, 2003; Lakoff \& Johnson, 2003) and ethnolinguistic discourse analysis (Underhill, 2011) to uncover beliefs which are implicitly expressed by teachers in discourse. Ethnolinguistic discourse analysis is a form of analysis which focuses on recurrent conceptual metaphors and cultural keywords in discourse (Underhill, 2011). In this study, the focus is on metaphors.

This concludes the Results section, and in the Discussion, I move on to discuss how these different perspectives on beliefs and practice may contribute to our understanding of the role that these teachers' beliefs have played in the specific teaching practice and affordances for language awareness observed.

\section{Results}

\subsection{Classroom practice}

The teaching activity played out very differently in the two teachers' classrooms. The most obvious difference is that in Teacher A's class (OA), the activity was introduced in the way originally proposed by the researcher, giving the students the machine-translated version of the text as the starting point, whereas Teacher $\mathrm{B}(\mathrm{OB})$ introduced an extra element by asking the students to first do a translation of their own. This changed the focus of the activity and extended its length. In Teacher A's class, the activity originally planned to last 90 minutes was conducted within a total time of 45 minutes, whereas in Teacher B's, it continued across several double periods. These deviations can be characterized as Teacher A limiting and Teacher B widening the timeframe of the activity. This limitation and widening can be said of the scope of the learning goals too; whereas Teacher A provided a tight framing and clear focus of the activity by reading out the machine translation, and modelling how mistranslations could be identified by back translations into English and dictionary searches (see Appendix 1, Transcript A), Teacher B added new elements by having students do their own translation and by providing students with a theoretical explanation of the use of the dictionary (see Appendix 1, Transcript B) and on the difficulties of translation while leaving the practical application of this knowledge up to the students.

The phrasing of the student task by the two teachers also differed considerably. Teacher A said to the students:

(1) "I skal skrive den om, så det giver mening."

(You have to re-write it [the Danish text] so that it makes sense.) Teacher A (OA)

By formulating this aim and by adding a focus on spelling and punctuation and an element of digitization, Teacher A provided a product-oriented end goal for all students: producing a correct, digital version of the text. This may have contributed to the quiet focus of the students in her class, since they were all able to engage in this task - even if they did not notice anything out of place in the text, they could still focus on typing it into their Google Doc.

Teacher B posed different tasks, one being the translation itself, the other being a more open-ended version of the engagement with the machine translated text: 
(2) “Nogle steder, der lyder det mystisk. Hvorfor er det, maskinen laver fejl? Hvad er det for nogle sammenhænge og ord, den ikke kan finde ud af? Jeres opgave med den danske tekst, det er at sætte streg under de steder, der er noget, der er forkert og finde ud af, hvorfor er det så det?"

(In some places, it sounds strange. Why does the machine make these mistakes? Which words and connections can't it work out? Your job with the Danish text is to underline the places where something is wrong and then figure out why.) Teacher $\mathrm{B}(\mathrm{OB})$

Clearly, this instruction puts the focus on metalinguistic reflection and requires the students to notice (cf. Schmidt, 1995) and point out specific out-of-place expressions in the text. In principle, this bilingual task could have created a bilingual or even plurilingual affordances for language aw areness, since students were invited to consider the two versions of the text and the differences and similarities between them in both form and meaning, thus allowing for generalised reflections on form-meaning relationships, cross-linguistic correspondances and the nature of (machine) translation. However, this openended task was perhaps less accessible to students. Some students worked diligently, displaying advanced metalinguistic reflection and exploring the connections between the two texts, whereas others played around, clearly not engaging with the task given. Some pairs of students displayed clear signs of frustration with the task, and others simply gave up.

The two teachers positioned themselves differently during class, Teacher A providing a very high degree of scaffolding and pre-empting problems before they occurred by bringing specific difficulties raised by individual students to the attention of the whole class (see Appendix 1, Transcript A), whereas Teacher B engaged with students on an individual level, providing only enough scaffolding to allow each student to reach their own conclusions. Teacher B tolerated a relatively high level of distraction, focusing his energy on helping the students that requested help, whereas Teacher A required her students to work quietly in their groups and made comments to the whole class at regular intervals.

Table 2 summarizes these differences between the two teachers' implementation of the teaching activity.

Table 2. Salient teaching practices.

\begin{tabular}{|c|c|c|}
\hline Teacher & $\mathbf{A}$ & B \\
\hline Structure \& timing & $\begin{array}{l}\text { - Brief teacher introduction } \\
\text { Time split evenly between: } \\
\text { - Group work } \\
\text { - Teacher-led discussion }\end{array}$ & $\begin{array}{l}\text { - Medium-length teacher } \\
\text { introduction } \\
\text { - Lengthy group work } \\
\text { - Very brief teacher-led discussion }\end{array}$ \\
\hline $\begin{array}{l}\text { Learning goals } \\
\text { presented in class }\end{array}$ & $\begin{array}{l}\text { To be aware what may happen } \\
\text { in translation }\end{array}$ & $\begin{array}{l}\text { To learn about dictionary use and } \\
\text { translation }\end{array}$ \\
\hline Task presented & $\begin{array}{l}\text { Re-writing the Danish text using } \\
\text { the computer }\end{array}$ & $\begin{array}{l}\text { - Translating the English text into } \\
\text { Danish with the use of dictionaries } \\
\text { - Subsequently comparing machine } \\
\text { translation to own translation }\end{array}$ \\
\hline Student engagement & Students work quietly in groups & Highly variable \\
\hline Teacher roles & $\begin{array}{l}\text { A guide providing a clear } \\
\text { direction and roadmap }\end{array}$ & $\begin{array}{l}\text { An expert presenting students with } \\
\text { academic and linguistic background } \\
\text { knowledge }\end{array}$ \\
\hline
\end{tabular}




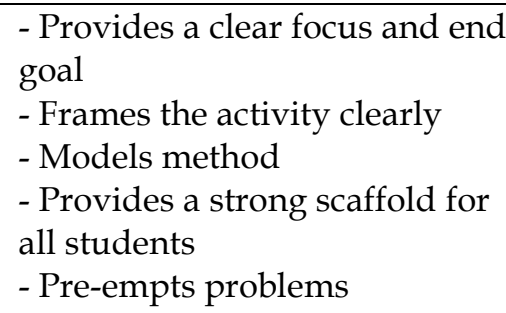

- Gives thorough presentation of dictionary use

- Discusses the pros and cons of Google Translate

A resource for students to seek out autonomously

- Allows students to work at their own pace

- Provides help on request

As evident from table 2, there are considerable differences between the way in which the teaching activity was implemented in the two classrooms. However, it is important to note that the teachers started off from the same point of departure and originally planned to do the same activity.

So the question is, what led them to put their common ideas into practice in such different ways? There are several obvious background factors which differ, such as the two teachers' relations to L1 and L2-teaching traditions respectively, which may have consequences for their perceptions of the activity, its learning goals, potentials and pitfalls. These perceptions may be understood as part of the teachers' beliefs about teaching and learning (some of which may have been formed through teacher training and others through experience, cf. Borg, 2011, 2018), and the choices that each teacher makes in the classroom may be seen as enactments of teacher beliefs.

\subsection{Enacted teacher beliefs}

The most salient characteristics of Teacher A's implementation of the activity may be described as: limitation in time and scope, providing a clear focus and end product of the task, modelling the task, strong scaffolding and pre-empting problems. In this section, I interpret these characteristics as enactments of teacher beliefs by considering what beliefs could meaningfully be attributed to a teacher choosing to implement the activity in this way. Given the interpretive nature of this analysis, alternative interpretations would be possible, and the exact phrasing of the enacted beliefs have been chosen by the researcher in an attempt to highlight the underlying meaningfulness of each teacher's practice (cf. Alvesson \& Sköldberg, 2009 Kubanyiova, 2020).

Some of the salient practices of Teacher A seem clearly related - modelling the task, strong scaffolding and pre-empting problems all seem to reflect a concern that students need clear guidance and that the difficulty level of the task should match the students' current level. This concern might be paraphrased students need teaching at their own level. If we attribute this belief to Teacher A, we see that it may help explain many of the dynamic choices she makes - by modelling and scaffolding, she matches the activity closely to the students' level, and by pre-empting problems, she evens out any rough patches which may occur along the way.

One example of pre-emption relates to the English word 'wrist' which has been left untranslated in the machine translation and is falsely interpreted by some children as the equivalent of the Danish 'vrist.' When she notices this, Teacher A draws the attention of the whole class to this point to prevent other students from making the same mistake (see Appendix 1, Transcript A). In doing so, she also creates a plurilingual affordance for language awareness by contrasting similar forms with different meanings in two languages, but at the same time directs the 
students' attention strictly at the solving of the task rather than an open-ended plurilingual metalinguistic exploration of the text.

The scaffolding and pre-emption simultaneously seem to aim for a low degree of student frustration and may thus be understood to enact another belief: that learning should be pleasant (rather than frustrating). This is reminiscent of Centeno and Ponce (2019) who find beliefs related to students' emotions (establishing positive rather than negative emotions) enacted by the teacher in their study.

Considering how Teacher A provides a clear focus and end product of the task, this may be understood to enact a specific belief that students need explicit instructions in addition to the more general belief that students need teaching at their own level, and perhaps a third belief that a clear focus enhances learning, a belief also reflected in the teacher's modelling of the task.

The most thought-provoking characteristic of Teacher A's implementation of the activity was the limitation in time and scope. Since this limitation was a clear deviation from plan (by no means singular to this study, cf. Borg, 2003), the beliefs enacted by this practice may be considered to carry some weight. The limitation in time enacts a belief that covering ground matters, since the time won by this limitation is spent on standard course work. This allocation of time may be understood meaningfully as the consequence of a busy schedule for the class if one takes such a belief into account.

\section{Teacher B}

Teacher B's very different implementation of the teaching activity enacts different beliefs about teaching and learning. The most salient characteristics of his realisation of the teaching activity were: widening the time and scope of the activity, presenting students with new academic and linguistic background knowledge and allowing students to work at their own pace despite a high level of noise and distraction.

One of the most obvious differences between the two teachers' implementation of the activity relates to the time and scope, and when Teacher B widens both timeframe and scope, this is a different enactment of beliefs than Teacher A's.

The widening of the scope consists in the addition of two elements: a generalized presentation of the use of the bilingual dictionary (see Appendix 1, Transcript B), and the element of active translation. Both of these additions to the scope of the activity can be interpreted as enactments of the belief that the teaching of specific L2-skills such as translation and dictionary use is important, and the related beliefs that academic ambition is important and that students can be met with high expectations.

The widening of the timeframe seems like an unplanned choice which is made when the teacher realizes the extent of the task he has set the students (other studies have shown similar reasons for departure from lesson plans, cf. Borg, 2003). The added elements obviously take up more time, and when the teacher chooses to prolong the timeframe in response to this observation, he enacts a belief that an activity should be carried through to the end. This is in stark opposition to the choice of Teacher A, a fact that in itself highlights the importance of individual teacher beliefs in the implementation of an activity.

Presenting students with new academic and linguistic background knowledge is an unremarkable choice for any teacher. It becomes salient only when observed in contrast to the choice of Teacher A, who does not discuss to the same extent the context or aims of the activity, and constitutes a further enactment of the beliefs 
mentioned above pertaining to academic ambitions and high expectations of the students, enacted by Teacher B in several different ways:

- by discussing the pros and cons of Google Translate, by drawing the students' attention to the higher-order learning goals of this activity (to enable students to critically evaluate the quality of a machine translation and to understand the meaning-oriented nature of translation,) and by

- systematically explaining all the possible lexical correspondences of a single lexeme to introduce the students to the use of the dictionary. Rather than modelling its use in this specific activity, he presents the full structure of a dictionary entry, leaving the application of this knowledge up to the students.

A classroom practice which seems to point in a different direction is that Teacher $B$ allows students to work at their own pace despite a high level of noise and distraction. This practice may also be related to the teacher's high expectations of the students, since he apparently expects them to be able to deal with the activity independently. At the same time, it seems to enact a belief pertaining to the role of the teacher as an expert and a resource for the students to seek out rather than a manager of the class.

\subsection{Professed teacher beliefs}

At the pre-activity reflection meeting, the teachers and the researcher discussed in depth the Danish machine-translated text to be given to the students. This collaborative process gave a preliminary indication of the teachers' beliefs related to the activity. The teachers reflected on the learning goals associated with the activity and the students' possible reactions. We planned the activity as a crosslinguistic awareness-raising activity, but Teacher B also wanted to engage students in specific problems related to automated translation. He was very enthusiastic about the activity and argued for the addition of the translation element, professing a belief that the students would be able to cope with the text despite its difficulty, saying "det kan de sagtens" (they can do that easily, RM). Thus, the high expectations enacted in practice (cf. section 4.2) were completely aligned with the belief professed during the planning session.

Teacher A thought the activity might pose too complex a challenge for some students and that they might not be able to cope with it, as illustrated by the following quotes:

(3) "Det skal godt nok gøres simpelt, for det der kan de på ingen måde gøre”

(We have to make it simple, because they would never be able to do it like that [referring to the way in which we in the teacher-researcher team analysed the text])

(4) “Hvordan kan man tænke ind, at det skal være for hele klassen?" (How can we make sure this works for all students?) Teacher A, RM

Through these and similar remarks, teacher A professed the belief that the activity might be too difficult for the students. She also worried whether her own English skills would be sufficient:

(5) “Altså, det ville være sådan jeg ville kunne køre det fordi jeg ville ikke sådan kunne... i forhold til mit engelske ville jeg jo ikke kunne sidde og sige det fordi det her ord bliver 
oversat til det og sådan noget - altså det er mine engelskkundskaber slet ikke til overhovedet"

(I mean that is how I would be able to do it, because of my English I wouldn't be able to say this word is translated into that word and so on, my English isn't that good at all) Teacher A, RM

As evident from the quotes above, Teacher A showed a certain concern about the difficulty level of the teaching activity - both for her students and herself. These professed beliefs seem very much in line with the beliefs she subsequently enacted in the classroom.

The question then remains how these specific beliefs relate to the more general beliefs previously expressed by each teacher regarding language and language teaching, and what role these may have played in the process. Some such beliefs were identified in the data from the prior teacher interviews, and suggest a considerable difference between the two teachers' views of language on a more general level.

The professed beliefs about language by Teacher A, who teaches Danish L1, focus primarily on forms and structure:

(6) "Jeg synes egentlig ikke det er så kønt et sprog" (I actually don't think it's a very pretty language [Danish])

(7) "Jeg bider mange ord over - det er rigtig dumt, når man er dansklærer" (I bite off my endings - a silly thing to do for a Danish teacher) Teacher A, IA

Whereas the first of these comments shows a focus on phonological form, the latter comment shows an orientation towards the written standard language as well as a focus on correctness, clearly implying a normative, structural view of language. This focus seems completely in line with the fact that she instructs students to pay special attention to spelling and punctuation in the lesson observed.

For Teacher $\mathrm{B}$, the match between the teaching observed and the previously professed language-related beliefs is less clear. When discussing Danish, he expresses a normative, structural view of language similar to Teacher A's:

(8) “I det store hele synes jeg bare mest man hører sådan noget - 'ordinært' lyder så negativt, og det er ikke på den måde tænkt, men vi har sådan et standardsprog, og det er det vi bruger, og så taler vi sådan. Og så håber vi på, at Nudansk Ordbog optager de ord, som vi ikke kan finde ud af at sige rigtigt, fordi så behøver vi ikke ændre på det. Og det synes jeg er lidt ærgerligt.

(Generally, I think the language that one hears is - well, 'plain' sounds very negative, and I don't mean it that way, but we have kind of a standard language that we use, and that's how we talk. An then we just hope for the Dictionary of Contemporary Danish to take on board the words we can't say right, because then we won't have to change anything. And I find that a bit of a pity.) Teacher B, IB

This view of Danish seems at odds with the inclusive and additive view he expressed in relation to English. With statements like the following, he clearly expressed a belief in communicative language teaching with little explicit focus on form:

(9) “Det er sjovest at kunne tale engelsk. Og hvis man kan have det sjovt i engelsk med at tale engelsk, så kan man få det andet med bagefter." 
(The most fun is being able to speak English. And if you can have fun in English class by speaking English, then you can get everything else afterwards.) Teacher B, IB

Teacher B's discourse seems to imply two opposing views of language: language as a structural system to be acquired through explicit instruction and practice (Danish) and as an organic system which grows dynamically through social semiosis (English). However, each of these views of language is connected in his discourse to the L1 and L2 subjects respectively, and conform quite well with the tendencies within each language subject's teaching tradition in the Danish context (Bremholm et al., 2017; Slåttvik et al., 2020). In this way, Teacher B seems to be professing beliefs which are compatible with the teaching traditions in each of the langauge subjects he teaches, and most probably with the instruction and teacher training he received himself.

\subsection{Implicit teacher beliefs}

In this section, I move from the beliefs professed explicitly in teachers' discourse to those expressed only implicitly in the form of metaphors and implicature.

One example of this is the idea of teacher control found implicitly reflected in Teacher A's prior discourse in remarks such as "Jeg har dem, hvor jeg vil ha' dem" (I've got them where I want them (IA)). I see this belief of teacher control as very much in line with the role that she assumes in the classroom, providing a clear focus and keeping a tight rein on the class.

While some metaphors, presuppositions and implicatures may occur in discourse simply because they are conventional in a given language, as Underhill puts it, "metaphors highlight and hide" (2011, p. 26), and when certain less conventional metaphors occur recurrently in a speaker's discourse in relation to certain topics, it is worthwhile considering what these metaphors highlight about the speaker's perspective on that topic.

Interestingly, such recurring conceptual metaphors may be found in the two teachers' discourse on language learning. In Teacher A's case, a construction metaphor occurs in relation to L1-learning and teaching:

(10) "alt det der teknik" (all the technical stuff)

(11) "nu er det grundlæggende på plads" (now the foundations are laid)

(12) "alle grundelementerne er der, så nu er vi klar til at bygge ovenpå, niveauet op"

(all the basic elements are there, so now we are ready to build on top of this, one level upwards)

(13) "redskaber" (tools) ${ }^{1}$ Teacher A, IA

The use of this conceptual metaphor implying a belief that learning a language is a gradual, cumulative process aligns very well with the structural view of language found in her professed beliefs, but also with the beliefs enacted in her classroom - that students need explicit instruction and that a clear focus enhances learning. It also aligns well with her strategy of pre-empting problems and providing a strong scaffold; after all, these considerations seem more prudent in construction work than a pedagogy of exploration, trial and failure would be.

If we now consider all of Teacher A's salient teaching practices as well as her enacted, professed and implicit beliefs and the connections between them, this network of beliefs (Borg, 2018) may be depicted as in Figure 1 below. 


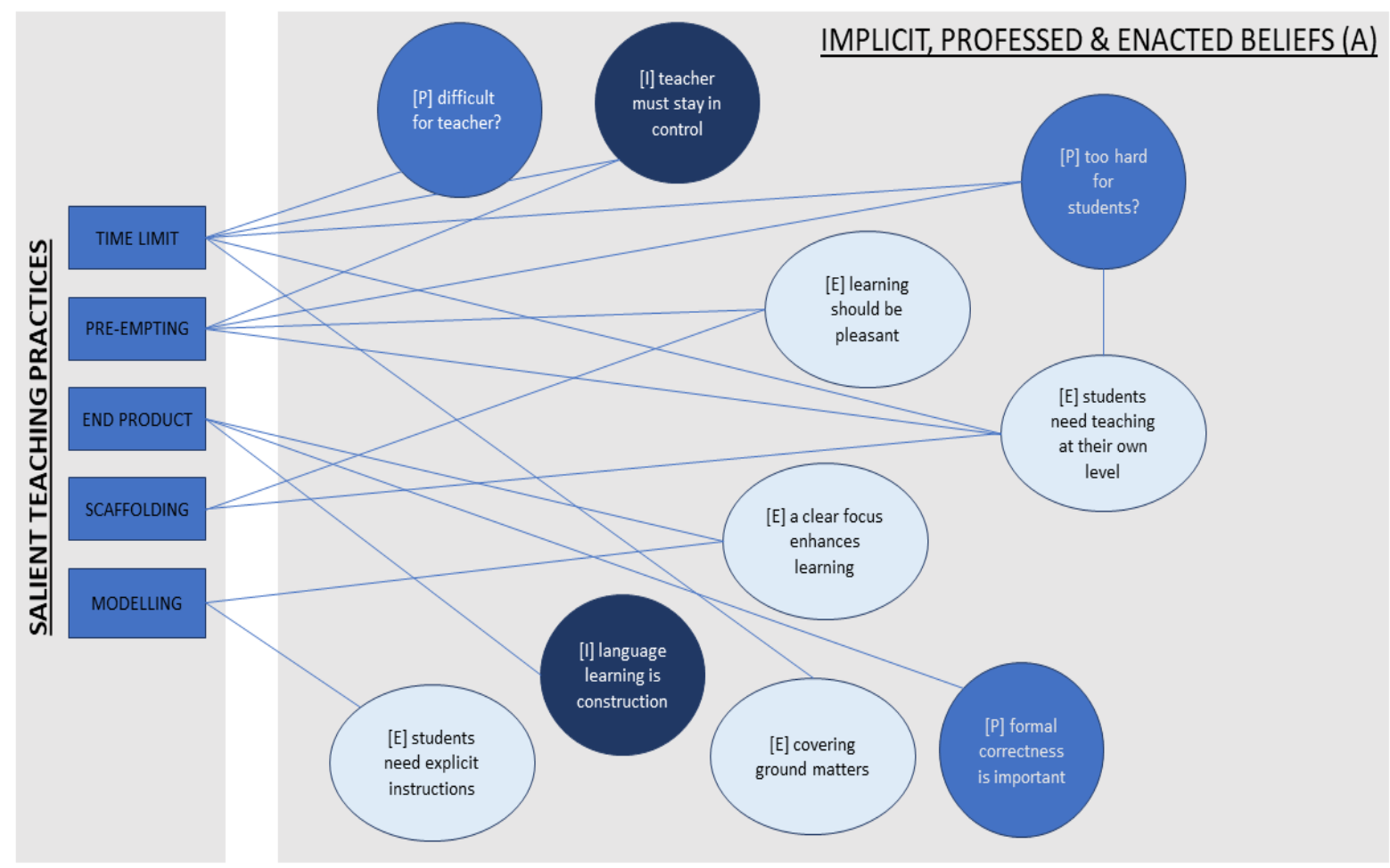

Figure 1. Implicit, professed and enacted beliefs of Teacher A. Squares indicate salient teaching practices, $[\mathrm{E}]$ enacted beliefs, $[\mathrm{P}]$ professed beliefs, $[\mathrm{I}]$ implicit beliefs.

As illustrated in Figure 1, all of the beliefs identified in some way relate to practices observed, and even the most unexpected classroom choice of limiting the timeframe of the activity may be viewed as meaningful in the context of Teacher A's beliefs.

In the case of Teacher B, similar observations can be made. He describes student learning by the use of a different conceptual metaphor: learning as seeing the light ${ }^{2}$.

(14) "Det er noget af det bedste, hvad skal man sige, når børn ser lyset"

(that is one of the best things, what do you call it, when children see the light)

(15) "når først de ser et glimt eller et lys eller et eller andet"

(as soon as they see a glimmer or a light or something) Teacher B, IB

This metaphor of learning clearly assigns the teacher to a different position: rather than overseeing the construction site, the teacher must open as many doors and windows as possible to allow for the light to flood the classroom.

In relation to the teaching observed, this makes sense, since what Teacher B does is present a lot of new background knowledge and let it be up to the students how they engage with the task and the background knowledge provided. He doesn't tell them exactly what to do or show them the application of the toolbox, he just provides what he deems to be the prerequisites to their "seeing the light".

Juxtaposing all of Teacher B's beliefs and salient practices in Figure 2 below illustrates how these, as in the case of Teacher A, may meaningfully be viewed as related in a complex network. 


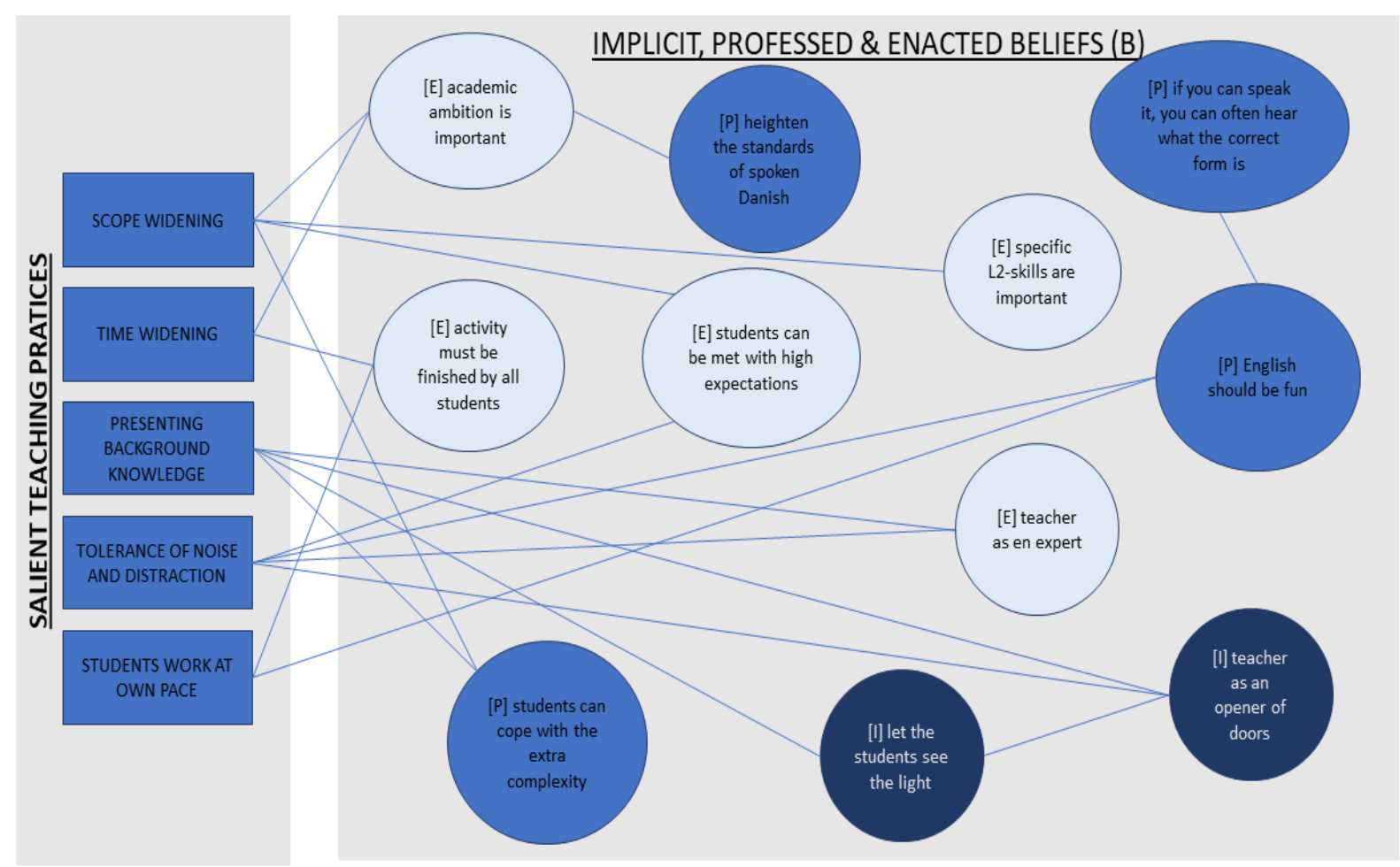

Figure 2. Implicit, professed and enacted beliefs of Teacher B. Squares indicate salient teaching practices, $[\mathrm{E}]$ enacted beliefs, $[\mathrm{P}]$ professed beliefs, $[\mathrm{I}]$ implicit beliefs.

\section{Discussion}

In the sections above, I have combined different sources of data and different analytical perspectives on teacher beliefs related to the two teachers' implementation of one specific teaching activity. The combination of the different perspectives yields an increasingly complex picture of a specific fragment of each teacher's belief network.

When examining the results of the analyses in figures 1 and 2, it becomes clear that none of the salient practices observed in the classroom can be seen as independent of teacher beliefs, even if they would not be fully explicable by focussing on professed beliefs only. The main contribution of this study is to combine the perspectives of enacted, professed and implicit beliefs in the attempt to paint a fuller picture of the complex interaction between teacher beliefs and teaching practice. Since the analyses in this study focused on one specific teaching activity, the results show one specific fragment of the teachers' beliefs network which came into play in relation to this activity. For a fuller picture of the two teachers' belief systems, more data should be included in the analysis. Nevertheless, the findings clearly show how the different implementations of a specific teaching activity may be meaningfully interpreted by considering the teachers' enacted, professed and implicit beliefs.

The study's primary limitations are related to its retrospective design, since the analysis raises questions that might have been answered through more focused teacher interviews closer in time to the lessons analysed, for example whether the background language learning and teaching beliefs of the teachers might have changed in the period between the initial interview and the observed classes or 
whether the teachers themselves agree with the interpretations given of their enacted beliefs in section 4.2.

However, since the inclusion of the beliefs professed in the prior interview contributes to the meaningfulness of the teachers' dynamic classroom choices, I see no reason to assume that these beliefs have changed in any major ways. Furthermore, as pointed out by previous research (Centeno \& Ponce, 2019; Woods, 2003), the beliefs that teachers enact in the classroom may not be fully conscious in the sense that a teacher or any other person does what seems right and meaningful in any situation without necessarily being able to explicate the full range of values and beliefs influencing any spontaneous choice, hence even if a follow-up interview had been possible, it might not have contributed any further to the explanation of these classroom choices.

As shown by previous research (Centeno \& Ponce, 2019; Kubanyiova, 2015), teachers' beliefs or self-images may sometimes be in internal conflict, and this may have consequences for teaching practice, as certain beliefs may be enacted more fully than others. This point is corroborated by my data, since the high academic ambitions professed and to a certain extent enacted by Teacher B seem to conflict with and to some degree be undermined by his relaxed classroom management style and the fact that many students simply don't engage with the task at hand.

In the case of Teacher A, her beliefs about teacher control and pleasant learning are enacted through careful classroom management, scaffolding and the limitation of time and scope. These beliefs related to classroom management and students' affective states seem to play a larger role than her beliefs related to language learning. This finding is reminiscent of Centeno and Ponce (2019), who similarly conclude that the beliefs connected to students' assumed emotions are the ones enacted in the classroom by the teacher in their study.

The comparison of the two teachers' implementation of the same teaching activity serves to highlight the role of the individual teacher in any implementation of new ideas. The analyses showed clear differences in the two teachers' implementation which may be explained in different ways, for instance with reference to the two teachers' different professional and personal backgrounds. However, my argument in this article is that while it is undoubtably true that the teachers' backgrounds play a role in forming their approaches to teaching, the concept of teacher beliefs allows us to take into account those aspects of their past, present and future which matter to the specific teachers in question.

The teaching activity at the locus of this study was designed to promote plurilingual affordances for language awareness. However, the affordances established in the classroom depended on the teachers' implementation, and clearly differed in the two classes, privileging different groups of students. In Teacher A's class, students with a stronger need of modelling and scaffolding were somewhat privileged at the expense of those who might have been able to deal with more complexity. Since difficulties and frustrations were pre-empted, even those students who might have been able to cope with insecurity and gain certain insights through independent attention to language and metalinguistic reflection were provided with so much scaffolding that they did not need to engage in an independent, explorative process.

In Teacher B's class, on the other hand, the more independent students were privileged. The expectation of autonomous learning and the limited amount of scaffolding and modelling provided this group of students with plurilingual 
affordances for explorative attention to language - the open-ended phrasing of questions by Teacher B allowed these students to engage with the texts in openended ways and to attend to both meaning and form. This also provided affordances for more open-ended forms of metalinguistic reflection, leaving it up to the students to judge the relevance of the resources provided and their existing metalinguistic knowledge.

In sum, the affordances for language awareness offered to the students depended on the way in which the two teachers transformed the collaboratively planned bilingual teaching activity into classroom practice. As shown in the previous sections, this transformation may be interpreted as an enactment of certain teacher beliefs, and this interpretation may be complemented by the inclusion of data on teachers' professed and implicit beliefs. Combining these three perspectives on teacher beliefs allows us a glimpse of the complexity of the relationship between a planned teaching activity and the actual teaching practice.

\section{Conclusion}

This study set out from an empirical rich point - two very different implementations of the same teaching activity. Through the consideration of enacted, professed and implicit beliefs, we found a close, but complex interconnection between teaching practice and teacher beliefs. As pointed out by Borg (2006: 275), this interconnection must be understood as "neither linear nor unidirectional", but rather as part of a complex dynamic network. The situatedness of the belief networks found reaffirms the need for an ecological perspective as called for by Kubanyiova \& Feryok (2015).

As pointed out by Kubanyiova \& Feryok (2015, p. 440), the study of teacher beliefs is the study of (parts of) teachers' inner lives and these are nested in larger ecologies connecting schools, curricula and teachers' "larger lives". In regard to these specific teachers and the ecology of which their practice forms a part, previous analyses (Krogager Andersen, 2020) have shown that the teachers' perspectives on the national curriculum, school planning and resources and on the groups of students involved also influence their planning and practice.

Teaching is a complex, intersubjective practice, and its interplay with teacher beliefs adds another layer of complexity. However, in a classroom-based study of teaching such as the present, acknowledging this complexity and its connection to teacher beliefs helps the researcher to make sense of the unpredictability in real-life teaching.

At the same time, the study shows us the precariousness of intervention-based classroom studies. If so much depends on the individual teacher, how can the findings of any study be applied to other contexts? Maybe the first step is to make sure the teacher's perspective is taken into account in the analysis. In any case, the interplay between teaching activities, students' engagements and teacher beliefs seem to be a fruitful place of inquiry for future research. 


\section{Acknowledgements}

In the writing process, I was fortunate to enjoy insightful response and helpful feedback on my first and second drafts from Maria Ruohotie-Lyhty \& Anne PitkänenHuhta, and on the final drafts from Anke Piekut \& Maria Pia Petterson. Thank you so much for your time, work and kindness. I would also like to thank the anonymous reviewers who contributed with valuable constructive feedback on the submitted paper.

\section{Endnotes}

1 These quotes and their relation to the construction metaphor is also described in Krogager Andersen (2020, in Danish).

2 For more on this, see Krogager Andersen (2020).

\section{References}

Agar, M. (2000). Border lessons: Linguistic "rich points" and evaluative understanding. New directions for evaluation, 2000(86), 93-109.

Alvesson, M., \& Sköldberg, K. (2009). Reflexive methodology: new vistas for qualitative research. SAGE.

Ammar, A., Lightbown, P. M., \& Spada, N. (2010). Awareness of L1/L2 differences: Does it matter? Language Awareness, 19 (2), 129-146. https://doi.org/10.1080/09658411003746612

Amrani, C., Hvidtfelt Lorentzen, A. K., \& Krogager Andersen, L. (2019) Tværsproglige læringsrum [Crosslinguistic learning spaces]. Sprogforum (68), 38-45.

Andersen, H. L., \& Blach, C. (2010). Tysk og fransk fra grundskole til universitetet: sprogundervisning $i$ et længdeperspektiv. [German and French in a longitudinal perspective]. Aarhus Universitetsforlag.

Andrews, S., \& Lin, A. M. Y. (2018). Language awareness and teacher development. In P. Garrett, \& J. M. Cots (Eds.), The Routledge handbook for language awareness (pp. 57-74). Routledge.

Angelovska, T. (2018). Cross-linguistic awareness of adult L3 learners of English: A focus on metalinguistic reflections and proficiency. Language Awareness, 27(1-2), 136-152. https://doi.org/10.1080/09658416.2018.1431243

Bialystok, E. (2011). Reshaping the mind: The benefits of bilingualism. Canadian journal of experimental psychology/Revue canadienne de psychologie experimentale, 65(4), 229-235. https:// doi.org/10.1037/a0025406

Borg, S. (2003). Teacher cognition in grammar teaching: A literature review. Language Awareness, 12(2), 96-108. https:// doi.org/10.1080/09658410308667069

Borg, S. (2006). Teacher cognition and language education: research and practice. Continuum.

Borg, S. (2011). The impact of in-service teacher education on language teachers' beliefs. System, 39(3), 370-380. https:// doi.org/10.1016/j.system.2011.07.009

Borg, S. (2018). Teachers' beliefs and classroom practices. In P. Garrett, \& J. M. Cots (Eds.), The Routledge handbook of language awareness (pp. 75-91). Routledge.

Bradbury-Huang, H. (2010). What is good action research? Why the resurgent interest? Action Research, 8(1), 93-109. https://doi.org/10.1177/1476750310362435

Bremholm, J., Bundsgaard, J., Fougt, S., \& Skyggebjerg, A. (2017). Læremidlernes danskfag. [The Danish L1 subject viewed through its textbooks]. Aarhus Universitetsforlag.

Burns, D., \& \& Worsley, S. (2015). Seeing the system -participatory systemic inquiry. In D. Burns \& S. Worsley (Eds.), Navigating complexity in international development. Facilitating sustainable change at scale (pp. 59-99). Practical Action Publishing.

Caceres-Lorenzo, M. T. (2014). Variables in the development of metalinguistic reflection (L1) of multilingual students in the freshman year. Revista española de lingüística aplicada, 27(2), 275-296. https://doi.org/10.1075/resla.27.2.02cac 
Centeno, A., \& Ponce, S. (2019). Beliefs about oral corrective feedback in an Argentinean EFL university classroom: Their impact on a teacher's classroom actions. Apples Journal of Applied Language Studies, 13(3), 35-58.

Daryai-Hansen, P., Meister, M., \& Tonello, E. (2015). Das DELA-NOBA Projekt. Babylonia, 15(2), 38-43.

Daugaard, L. M. (2015). Sproglig praksis i og omkring modersmålsundervisning: En lingvistisk etnografisk undersøgelse [Linguistic practices in and around mother tongue teaching. A linguistic ethnographic case study of language teaching across the curriculum in a Danish primary school] [Doctoral dissertation, Aarhus University]. https://viden.sl.dk/media/ 5099/sproglig-praksis-i-og-omkring-modermaalsundervisning.pdf

Dufva, H., \& Alanen, R. (2005). Metalinguistic awareness in dialogue: Bakhtinian considerations. In J. K. Hall, G. Vitanova, \& L. Marchenkova (Eds.), Dialogue with Bakhtin on second and foreign language learning: New perspectives (pp. 432-451). Lawrence Erlbaum Associates.

EVA [Det Danske Evalueringsinstitut]. (2003). Engelsk i grundskolen - mål og resultater. [English in primary and lower secondary school - goals and results]. https://www.eva.dk/ grundskole/engelsk-grundskolen-maal-resultater

Fairclough, N. (1992). Critical language awareness. Longman.

Gunning, P., White, J., \& Busque, C. (2016). Raising learners' awareness through L1-L2 teacher collaboration. Language Awareness, 25(1-2), 72-88. https:// doi.org/10.1080/09658416.2015.1122022

Haukås, Å. (2016). Teachers' beliefs about multilingualism and a multilingual pedagogical approach. International Journal of Multilingualism, 13(1), 1-18. https://doi.org/10.1080/ 14790718.2015.1041960

Hawkins, E. W. (1999). Foreign language study and language awareness. Language Awareness, 8(3-4), 124-142. https://doi.org/10.1080/09658419908667124

Hersted, L., Ness, O., \& Frimann, S. (Eds.). (2020). Action research in a relational perspective: Dialogue, reflexivity, power and ethics. Routledge.

Hornberger, N. H. (2013). Negotiating methodological rich points in the ethnography of language policy. International Journal of the Sociology of Language, 2013(219), 101-122. https://doi.org/10.1515/ijsl-2013-0006

James, C., \& Garrett, P. (1992). Language awareness in the classroom. Longman.

Jessner, U. (1999). Metalinguistic awareness in multilinguals: Cognitive aspects of third language learning. Language Awareness, 8(3), 201-209. https://doi.org/10.1080/09658419908667129

Jessner, U. (2016). Multicompetence approaches to language proficiency development in multilingual education. In O. Garcia (Ed.), Bilingual and multilingual education, encyclopedia of language and education (pp. 161-173). Springer International Publishing.

Kalaja, P., Barcelos, F., Aro, M., \& Ruohotie-Lyhty, M. (2015). Beliefs, agency and identity in foreign language learning and teaching. Palgrave Macmillan.

Kramsch, C. (2003). Metaphor and the subjective construction of beliefs. In P. Kalaja \& F. Barcelos (Eds.), Beliefs about SLA (pp. 109-129). Kluwer Academic Publishers.

Krogager Andersen, L. (2020). Tværsproglighedens veje. Om sproglig bevidsthed, tværsproglighed og didaktisk forandringsarbejde $i$ en folkeskolekontekst [Plurilingual paths to language awareness. A collaborative investigation of affordances for language awareness established in the context of a plurilingual approach to language learning] [Doctoral dissertation, Aarhus University]. https://ebooks.au.dk/aul/catalog/book/361

Kubanyiova, M. (2015). The Role of teachers' future self guides in creating L2 development opportunities in teacher-led classroom discourse: Reclaiming the relevance of language teacher cognition. The Modern Language Journal, 99(3), 565-584. https://doi.org/10.1177/1362168818777533

Kubanyiova, M. (2016). Teacher development in action: Understanding language teachers' conceptual change. Palgrave Macmillan.

Kubanyiova, M. (2020). Language teacher education in the age of ambiguity: Educating responsive meaning makers in the world. Language Teaching Research, 24(1), 49-59. https://doi.org/10.1177/1362168818777533

Kubanyiova, M., \& Feryok, A. (2015). Language teacher cognition in applied linguistics research: Revisiting the territory, redrawing the boundaries, reclaiming the relevance. The Modern Language Journal, 99(3), 435-449. https://doi:10.1111/modl.12239 
Kvale, S., \& Brinkmann, S. (2009). Interview: Introduktion til et håndværk [Interview. An introduction to a craft]. Hans Reitzel.

Lakoff, G., \& Johnson, M. (2003). Metaphors we live by. University of Chicago Press.

Larsen-Freeman, D. (2000). Techniques and principles in language teaching. Oxford University Press.

Larsen-Freeman, D. \& L. Cameron (2008). Complex systems and applied linguistics. Oxford University Press.

Laursen, H. P. (2019). Tegn på sprog -set indefra [Signs of language - seen from the inside] Research report. https://www.kp.dk/wp-content/uploads/2020/01/tegn-paa-sprogset-indefra-2019.pdf

Li, L. (2013). The complexity of language teachers' beliefs and practice: One EFL teacher's theories. The Language Learning Journal, 41(2), 175-191. https:// doi.org/10.1080/09571736.2013.790132

Lier, L. V. (2004). The ecology and semiotics of language learning: A sociocultural perspective. Kluwer Academic Publishers.

McNamee, S. (2020). Action research as ethical practice: Coordinating voices, expanding possibilities. In L. Hersted, O. Ness, \& S. Frimann (Eds.), Action research in a relational perspective (pp. 224-241). Routledge.

Meier, G. S. (2016). The multilingual turn as a critical movement in education: Assumptions, challenges and a need for reflection. Applied Linguistics Review, 8(1) 131-161. https://doi.org/10.1515/applirev-2016-2010

Moore, D. (2014). Sproglig opmærksomhed: En tilgang til at styrke sproglæring fra den tidlige barndom [Language awareness: an approach to strengthen language learning from early childhood]. Sprogforum, 58, 41-48.

Oliveira, A. L., \& Ancâ, M. H. (2018). Language awareness and the development of learners' plurilingual competence. In P. Garrett \& J. M. Cots (Eds.), The Routledge handbook of language awareness. (pp. 238-256). Routledge.

Palfreyman, D. M., \& Al-Bataineh, A. (2018). 'This is my life style, Arabic and English': Students' attitudes to (trans)languaging in a bilingual university context. Language Awareness, 27(1-2), 79-95. https:// doi.org/10.1080/09658416.2018.1431244

Radinger, S. (2018). Language awareness and agency in the availability of linguistic resources. A case study of refugees and locals in Austria. Language Awareness, 27(1-2), 61-78. https://doi.org/10.1080/09658416.2018.1435674

Ruohotie-Lyhty, M. (2015). Stories of change and continuity: Understanding the development of the identities of foreign language teachers In P. Kalaja, F. Barcelos, M. Aro, \& M. Ruohotie-Lyhty (Eds.), Beliefs, agency and identity in foreign language learning and teaching (pp. 172-201). Palgrave Macmillan.

Sakui, K., \& Gaies, S. J. (2003). A case study: Beliefs and metaphors of a Japanese teacher of English. In P. Kalaja, \& A. M. F. Barcelos (Eds.), Beliefs about SLA: New research approaches (pp. 153-170). Springer.

Schmidt, R. W. (1995). Attention and awareness in foreign language learning. Second Language Teaching \& Curriculum Center, University of Hawai'i.

Simard, D., \& Gutiérrez, X. (2018). The study of metalinguistic constructs in second language acquisition research. In J. M. Cots \& P. Garrett (Eds.), The Routledge handbook of language awareness (pp. 205-221). Routledge.

Skott, J. (2015). The promises, problems, and prospects of research on teachers' beliefs. In H. Fives \& M. G. Gill (Eds.), International handbook of research on teachers' beliefs (pp. 13-30). Routledge.

Slåttvik, A. B., Daugaard, L. M., \& Jakobsen, A. S. (2020). Kvalitetsudvikling, brobygning og videreudvikling - en behovsundersøgelse i faget engelsk på tværs af uddannelsessystemet. [Improvement, bridging and development - an exploration into the needs within the subject of English across curricular levels]. https://ncff.dk/projekter/bevilligedeprojekter/behov-og-viden/

Underhill, J. W. (2011). Creating worldviews: metaphor, ideology and language. Edinburgh University Press.

Woods, D. (2003). The Social Construction of Beliefs in the Language Classroom. In P. Kalaja \& F. Barcelos (Eds.), Beliefs about SLA: New Research Approaches (pp. 201-229). Springer. 


\title{
Appendices
}

\author{
Appendix 1. \\ Transcript A (translated excerpts)
}

\section{Modelling}

Teacher A: Yes. You have a text now, it's called "Ancle and and 'wrist' [EN] sprains." And it is a text which was originally written in English and then it was translated by Google Translate. [inaudible] And why do you think we will be working with this? Why do you think we will look at this?

Student A: Because when you translate something, you have to kind of pay attention because maybe the direct translation doesn't make sense.

Teacher A: Exactly. It is to pay attention to how these translations work and how sometimes it makes sense and sometimes it makes no sense at all. And that is quite clear when you get a text like this in Danish. Like this one. It might be more difficult the other way around. If we were to take a Danish text and put it in Google Translate and it would come out in English. And especially when you're in $5^{\text {th }}$ grade and working at becoming very very good at English, and even German, then it is very important to learn to pay attention to this and how you translate. I will read it out to you.

Teacher A reads out the text.

Teacher A: And this text made a lot of sense when it was in English and some of it still makes sense in Danish, but there are definitely some parts that don't make much sense. And our job now - or yours - is, in a minute, you'll get a computer, and you will re-write this text, just in Danish. You have to rewrite it so that it makes sense, change the sentences. You can't change the meanings, but move things around and check out the grammar, maybe some endings that don't make sense, and there are some words, too. "A sprain is what happens when a ligament stretches or 'tears' [noun, pl.]" How can a ligament 'tear' [noun, sg.]? Does it mean it cries? In this case, if you don't know what this word could have been originally, you can go to the dictionary - have you done this before?

Students: Yes.

Teacher A: Alright, so you know it. We go here and choose English-Danish-English. Aaand. I try to do a search. And I try to look for

[techical intermezzo]

Teacher A: Like this. Search. I enter 'tåre' and it says 'tear'. 'Tears were rolling down his cheek' $[\mathrm{EN}]$ So tears rolling down his cheek [DA]. But we have this 'tear' [EN] which is what it wants to translate it into. But if we enter 'tear' [EN] it says 'tear' [noun, teardrops]. Tear [noun, a tear in a piece of fabric], it could be. We could have a look down here. 'Tear up', it could be. 'Tear apart' Might any of these words be a better match? [Student A]?

Student A: That one, 'tear apart.'

Teacher A: "A sprain is what happens when a ligament stretches or tears [verb]" In this way, try to have a look at the dictionaries. And check out with these words that don't make sense, if we have a look in the dictionary, we might find a better option. 


\section{Pre-empting}

After the students start working, Teacher A notices a problem in one student's text and calls out to the class.

Teacher A: try to look up 'wrist' [EN], ok? Because I see that many of you are just entering it into your title. Can anyone tell me, what 'wrist' [EN] means in Danish?

Student A: Isn't it just 'vrist' ['top of the foot']

Student B: No, it's 'håndled' ['wrist']

Teacher A: Go and have a look in the dictionary what 'wrist' really means. 'Vrist?'

\section{Transcript B (translated excerpts)}

\section{Dictionary use}

Teacher B: All right - now we're going to have a look, what is a dictionary?

Teacher B opens a digital dictionary (ordbogen.com) on the class smartboard and enters "løb," [author's note: a word which has multiple correspondences in English, belonging to different word classes 'run' verb and noun, 'race,' 'barrel,' 'course' etc.] . Teacher B reads out every part of the dictionary entry, explaining how translations may go wrong if the wrong word is chosen. He then moves on to the verb 'to run' and repeats the procedure.

Teacher B: You can't just take the first and best word you see, you have to consider what does it means in the context of the sentence.

$[\ldots]$

Teacher B: You get an extraordinary number of options as to how the word may be used and what the correct translation would be. What you have to remember is that what you want to translate is not so much the words, it is the meaning. What does that mean [student $\mathrm{A}$ ]?

Student A: That you have to translate the meaning of the whole sentence

Student B: Can't we just look up the entire sentence?

Teacher B: No. Some [students] think that this is a bad dictionary because you have to look up the sentence, generally speaking, one word at a time. 